\title{
Yield and Quality of Lettuce and Rocket Grown in Floating Culture System
}

\section{Spyridon A. PETROPOULOS ${ }^{1 *}$, Eleni CHATZIEUSTRATIOU ${ }^{2}$, Eleni CONSTANTOPOULOU², George KAPOTIS ${ }^{2}$}

\author{
${ }^{I}$ University of Thessaly, Laboratory of Vegetable Production, Fytokou Str. Nea Ionia 38446 Volos, \\ Greece; spetropoulos@uth.gr (*correspondingauthor) \\ ${ }^{2}$ TEI of Messolonghi, Department of Greenhouse Crops and Floriculture, Laboratory of Vegetable Production, Nea Ktiria 30200, Messolonghi, \\ Greece; chatzieustratiou@yahoo.gr; gialeni@hol.gr; kapotis@teimes.gr
}

\begin{abstract}
In recent years, there has been a growing trend towards cultivating leafy vegetables in hydroponic systems. Floating system is an alternative hydroponic system suitable for the production of baby vegetable products, ready-to eat salads and minimally processed leafy vegetables. However, the implementation of this system for the production of fully grown leafy vegetables is not sufficiently studied. The aim of the present study was to examine the potential of floating system as an alternative growing technique of lettuce and rocket plants, as well as the effect of nitrogen $(\mathrm{N})$ application rate (three treatments 100, 150 and 200 $\mathrm{mg} \mathrm{L}^{-1}$ of $\mathrm{N}$ ) on plant physiology, quality and yield during three growing periods. The results showed that increasing the $\mathrm{N}$ application rate resulted in an increase of fresh weight of the aerial parts of both lettuce and rocket, while total yield ranged between 12.0 to 41.9 and 8.0 to $30.2 \mathrm{~kg} \mathrm{~m}^{-2}$ of fresh leaves, for lettuce and rocket, respectively. In addition, increasing the nitrogen rate resulted in higher number of leaves for lettuce and rocket, as well as in a significant increase in the rate of photosynthesis. A similar increase was observed in nitrate, $\mathrm{K}, \mathrm{Mg}$ and $\mathrm{Mn}$ content in the leaves, without however exceeding the permissible limits for nitrates in any case. In conclusion, the use of floating raft technique for lettuce and rocket cultivation in order to produce not only seedlings production or baby products, but also fully grown plants of high quality is highly recommended.
\end{abstract}

Keywords: Eruca sativa, floating system, Lactuca sativa, nitrate content, photosynthetic rate, soilless culture, transpiration rate

\section{Introduction}

Floating system technique is a closed hydroponic system widely used for the production of seedlings of tobacco plants and leafy vegetables species. Due to a growing interest for baby vegetable products (lettuce, rocket, spinach and so forth), this technique is a useful means for producing premium products, since vegetables quality is severely affected by pre- and postharvest treatments (Rouphael et al., 2004). During the last years, vegetable production of processed and minimally processed products (fresh-cut products, mixed salads, baby products and so forth) in soilless culture techniques, including floating system, has gained significant interest (Soundy et al., 2001; Salerno et al., 2005; Nicola et al., 2005; Conesa et al., 2009; Fallovo et al., 2009a,b; Fontana and Nicola, 2009; Zanin et al., 2011; Klados and Tzortzakis, 2014).

Such a technique combines the advantages of hydroponic cultivation with higher savings of water, fertilizers, time, labor and space, higher surviving rates of young seedlings during and after transplanting, heating of nutrient solution and therefore an improved nutrient uptake from roots and higher yield comparing to conventional production systems, and most importantly it is an eco-friendly technique (Soundy and Cantliffe, 2001; Fallovo et al., 2009a,b; Kotsiras et al., 2016). Nicola et al. (2005) reported that rocket plants grown in a soilless culture system had higher fresh leaf production in a shorter time period, compared to plants cultivated in soil, resulting in a higher total production of leaves. Moreover, Manzocco et al. (2011) reported that lamb's lettuce plants grown hydroponically showed an increased yield and overall quality compared to soil-cultivated plants.

Especially for leafy vegetables such as lettuce and rocket, plants cultivated in floating system show uniformity in seedlings development and plant growth and consequently in transplanting and harvesting time, which could be mechanized allowing for further cost reduction (Gonnella et al., 2001). 
604

Fontana and Nicola (2009) reported that rocket plants grown in floating system showed higher fresh mass yield and enhanced earliness, in comparison with plants grown in soil. Furthermore, nitrate content of leaves, which is considered a major quality feature for leafy vegetables, was higher for plants grown in soilless culture systems than those grown in soil, but in either case did not exceed the limit imposed by the European Commission (EC Reg. No. 1258/2011) for lettuce grown under cover and harvested from April $1^{\text {st }}$ to September $30^{\text {th }}$ (4000 $\mathrm{mg} \mathrm{kg}^{-1}$ f.w.).

Considering the nutrient management options that soilless culture systems provide, plants nutrient requirements are easier to fulfill, resulting in products of high quality, less nutrients deficiency symptoms that affect visual appearance and better consumers' acceptance. Moreover, the potential of custom formulations of nutrient solutions can be a useful means towards micronutrients' biofortification of the final product, as well as the addition of non-essential minerals (Tomasi et al., 2015). Coronel et al. (2009) reported that chlorophyll content and nitrate reductase activity was greater in lettuce plants grown hydroponically than in plants grown with traditional methods. Apart from plant growth and yield, nutrient solution composition may also affect quality features such as dry matter, nitrate, chlorophyll and mineral content (Galbiatti et al., 2007; Fallovo et al., 2009a,b). For example, Soundy et al. (2001) reported that $\mathrm{P}$ concentration of irrigation water in the range of 35 to $50 \mathrm{mg} \mathrm{L}^{-1}$ is essential for producing high quality lettuce seedlings, while Conesa et al. (2009) reported that nitrate/ammonium ratio of nutrient solution in floating systems is of major importance for the yield and quality of baby leaf spinach and bladder campion plants.

Other cultivation features such as high salinity of nutrient solution (up to $4.8 \mathrm{mS} \mathrm{cm}^{-1}$ ), plant density and growing season could also affect yield and quality (nitrates, chlorophylls, vitamin $C$, carbohydrates and minerals content) of radish (Raphanus sativus), lamb's lettuce or corn salad (Valerianella locusta), rocket (Eruca sativa), artichoke (Cynara scolymus), cardoon (Cynara cardunculus), spiny chicory (Cichorium spinosum), and lettuce (Lactuca sativa) plants (Salerno et al., 2005; Fallovo et al., 2009a,b; Fontana and Nicola, 2009; Scuderi et al., 2009; Zanin et al., 2011; Colla et al.2012; Klados and Tzortzakis, 2014). Default et al. (2006) reported that cultivation season affected significantly the growth rate and yield of six Cos type lettuce cultivars. Sowing in September or April resulted in a shorter growth cycle than sowing in December or January, while seasonal increases in temperature increased the photosynthetic rate up to a threshold, above which damage to the photosynthetic enzymes and stomatal closure occurred (Thebud and Santarius, 1982).

In higher plants, conditions of low light intensity cause a slight increase in the size of the LHCII compex and a reduction in the chlorophyll a/b ratio (Larsson et al., 1987). The a/b ratio relates to the developmental stage of the photosynthetic tissues and the maturity of the leaf (Schoefs et al., 1998). Thus, although the outer, dark green leaves of Cos lettuce cultivars have a higher total chlorophyll content than the intermediate and inner leaves, they have a lower $\mathrm{a} / \mathrm{b}$ ratio (Henriques and Park, 1976). Leaf chlorophyll content is also correlated with the $\mathrm{N}$ application rate (Fritschi and Ray, 2007) and can therefore be used as a means of assessing $\mathrm{N}$ availability within the nutrient solution (Torres et al., 2005).
The aim of the present study was to evaluate the effect of three nitrogen levels $\left(100,150\right.$ and $\left.200 \mathrm{mg} \mathrm{L}^{-1}\right)$ on physiology (net photosynthetic and transpiration rate), development, yield (number of leaves, fresh and dry weight) and quality (vitamin $\mathrm{C}$, nitrates and minerals content) of lettuce and rocket plants grown in a floating system for three growing periods. In addition, the innovative feature of the present study is the evaluation of implementing floating system culture not only for seedlings production, but also for fully grown plants of marketable size.

\section{Materials and Methods}

\section{Plant material and experimental conditions}

Experiments were carried out in three growing periods in a partly automated heated glasshouse at the Technological Institute of Messolonghi, Messolonghi, Greece (latitude 38 $36^{\prime}$ $64^{\prime \prime}$, longitude $21^{\circ} 47^{\prime} 65^{\prime \prime}$, height above sea level $19 \mathrm{~m}$ ). Lettuce (Lactuca sativa cv. 'Parris Island', Cos type) and rocket plants (Eruca sativa) were provided by Geniki Fytotechniki S.A. and grown in a floating raft system. The system consisted of 9 closed and independent tanks where both plant species were grown together in separate polystyrene trays (three trays for each species and six trays in each tank in total), each one having a constant volume of $200 \mathrm{~L}$ of nutrient solution $(1.1 \times 1.2 \mathrm{x}$ $0.20 \mathrm{~m}$ ) and consisting one experimental unit. Two air pumps (air flow of $500 \mathrm{~L} \mathrm{~h}^{-1}$ ) were sunk into each tank for the adequate aeration and stirring of nutrient solution. Replenishment of nutrient solution in each tank was activated by a floating device and applied via graded plastic containers of $60 \mathrm{~L}$ containing the appropriate nutrient solution. The $\mathrm{pH}$ and electric conductivity (EC) of all nutrient solutions was retained at the level of 5.6 and $2.0 \mathrm{dS} \mathrm{m} \mathrm{m}^{-1}$ respectively, throughout the experiments. Nutrient solution was prepared by diluting stock solutions in tap water in order to achieve the composition for the application rates of 100,150 and $200 \mathrm{mg}$ $\mathrm{L}^{-1}$ of nitrogen $(\mathrm{N})$ as presented in Table 1 , while $\mathrm{N}$ was applied in the form of $\mathrm{Ca}\left(\mathrm{NO}_{3}\right)_{2}, \mathrm{KNO}_{3}, \mathrm{NH}_{4} \mathrm{NO}_{3}$ and $\mathrm{Mg}\left(\mathrm{NO}_{3}\right)_{2}$ with the appropriate amounts for each nutrient solution.

Plants were transplanted at the stage of two to three true leaves, on April $10^{\text {th }}$ (year 1 and 2) and April $14^{\text {th }}$ (year 3), in expanded polystyrene trays (experiments 1,2 and 3 , respectively) containing peat and perlite $(1: 1 \mathrm{v} / \mathrm{v})$, watered and put in the tanks. The planting density was 150 and 75 plants $\mathrm{m}$ ${ }^{2}$ for rocket and lettuce respectively (100 and 50 plants in each replication for rocket and lettuce respectively), according to plant densities that are used commercially for similar leafy vegetables. After transplanting, plants were treated with three $\mathrm{N}$ application rates, namely 100,150 and $200 \mathrm{mg} \mathrm{L}^{-1}$ of $\mathrm{N}$, until the day of harvest on $20^{\text {th }}$ of May (year 1 and 2) and the $24^{\text {th }}$ of May (year 3), for experiments 1, 2 and 3 respectively. Mean, maximum and minimum temperatures for April and May of the experimental years are presented in Fig. 1 .

\section{Data collection}

During cultivation and until harvest time $(17,25,31,35$ and 40 days after transplanting and treatment initiation), measurements were recorded in situ for the net photosynthetic and transpiration rate, while fresh samples were taken in order to evaluate fresh and dry weight of leaves. Net photosynthesis $\left(\mu \mathrm{mol} \mathrm{CO} \mathrm{Cm}^{-2} \mathrm{~s}^{-1}\right)$ and transpiration rate $\left(\mathrm{mmol} \mathrm{m} \mathrm{s}^{-1}\right)$ were 
Table 1. Electrical conductivity, $\mathrm{pH}$, macro- and micro-nutrient composition of the tested nutrient solutions

\begin{tabular}{cccc}
\hline \multirow{2}{*}{ Parameter } & \multicolumn{3}{c}{ Nitrogen application rate $\left(\mathrm{mg} \mathrm{L}^{-1}\right)$} \\
\cline { 2 - 4 } & 100 & 150 & 200 \\
\hline $\mathrm{EC}(\mathrm{dS} / \mathrm{m})$ & 2.00 & 2.00 & 2.00 \\
$\mathrm{pH}$ opt. & 5.60 & 5.60 & 5.60 \\
{$[\mathrm{~K}] \mathrm{mmol} / \mathrm{l}$} & 6.00 & 6.00 & 6.00 \\
{$[\mathrm{Ca}] \mathrm{mmol} / \mathrm{l}$} & 3.50 & 3.50 & 3.50 \\
{$[\mathrm{Mg}] \mathrm{mmol} / \mathrm{l}$} & 2.00 & 2.00 & 2.00 \\
{$[\mathrm{NO}] \mathrm{mmol} / \mathrm{l}$} & 6.14 & 9.71 & 13.29 \\
{$[\mathrm{NH} 4] \mathrm{mmol} / 1$} & 1.00 & 1.00 & 1.00 \\
{$[\mathrm{H} 2 \mathrm{PO} 4-] \mathrm{mmol} / \mathrm{l}$} & 1.20 & 1.200 & 1.20 \\
{$[\mathrm{Fe}] \mu \mathrm{mol} / 1$} & 25.00 & 25.00 & 25.00 \\
{$[\mathrm{Mn}] \mu \mathrm{mol} / \mathrm{l}$} & 10.00 & 10.00 & 10.00 \\
{$[\mathrm{Zn}] \mu \mathrm{mol} / \mathrm{l}$} & 4.00 & 4.00 & 4.00 \\
{$[\mathrm{Cu}] \mu \mathrm{mol} / \mathrm{l}$} & 0.70 & 0.70 & 0.70 \\
\hline$[\mathrm{B}] \mu \mathrm{mol} / \mathrm{l}$ & 30.00 & 30.00 & 30.00 \\
\hline $\mathrm{Mo}] \mu \mathrm{mol} / \mathrm{l}$ & 0.50 & 0.50 & 0.50 \\
\hline $\mathrm{Si}] \mathrm{mmol} / \mathrm{l}$ & 0.00 & 0.00 & 0.00 \\
\hline
\end{tabular}

measured on fully expanded leaves under sunlight conditions and ambient concentrations of $\mathrm{CO}_{2}$ and $\mathrm{O}_{2}$, between 09:00 and 12:30 with an LCi Portable Photosynthesis System (ADC BioScientific, Hoddesdon, Herts, UK). Leaf chamber temperature was kept in accordance with ambient temperature $\left( \pm 1^{\circ} \mathrm{C}\right)$, with the use of the climate control capability of the instrument.

On the day of the final harvest ( 40 days after transplanting and treatment initiation, and when plants reached a marketable size), fresh and dry weight and number of leaves of each plant were recorded, while eight plants per treatment were randomly selected for further analysis of the mineral content of leaves. Samples of plant tissues were dried in a forced-air oven at $72^{\circ} \mathrm{C}$ to constant weight and the dry weight was measured. To determine the mineral content, samples were powdered using a ball-mill, passed through a 40-mesh sieve, subjected to dry ashing in a muffle furnace at $550^{\circ} \mathrm{C}$ for $5 \mathrm{~h}$, and dry powder was used to extract $\mathrm{K}, \mathrm{Mg}, \mathrm{Fe}, \mathrm{Mn}, \mathrm{Zn}$, and $\mathrm{Cu}$ by means of 1 N HCl (Campbell and Plank, 1998). The concentrations of $\mathrm{Mn}, \mathrm{Mg}, \mathrm{Fe}, \mathrm{Zn}$, and $\mathrm{Cu}$ in the aqueous extracts were determined by atomic absorption spectrophotometry (Perkin Elmer 1100B, Waltham, MA) and $\mathrm{K}$ by flame photometry (Sherwood Model 410, Cambridge, UK).

Vitamin C content in leaves was determined by the method of Bajaj and Kaur (1981) using a Shimadzu Spectrophotometer Model UV-1601 VIS (Shimadzu, Kyoto, Japan). For each sampling date of the three experiments (11, 25,31 and 40 days), four plants of lettuce and rocket from each replicate were harvested and extracts were prepared from the middle, fully mature leaves.

The total chlorophyll content of the leaves was determined by the method of Wellburn (1994), based on acetone extraction of the chlorophyll and a colorimetric assay with the aid of a Shimadzu Spectrophotometer Model UV-1601 VIS (Shimadzu, Kyoto, Japan). Total chlorophyll content was estimated as the sum of chlorophyll $a$ and chlorophyll $b$

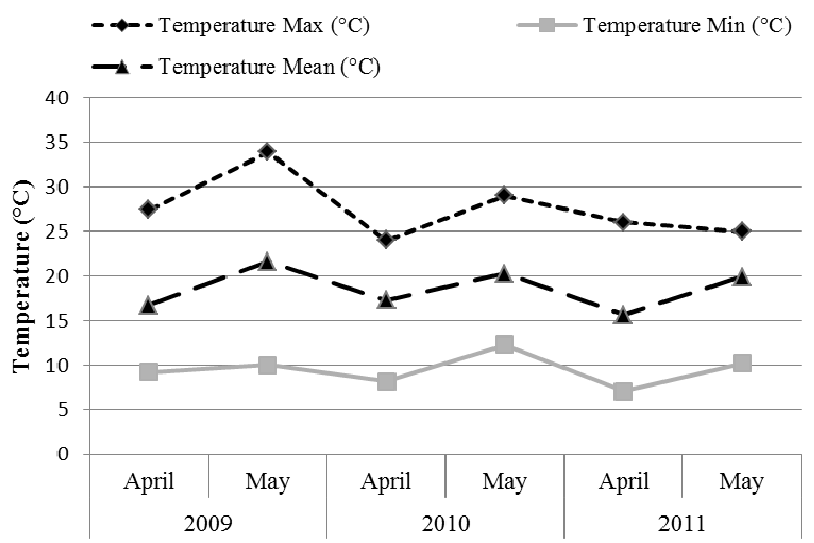

Fig. 1. Meteorological data during the experiment (max, min and mean temperature in ${ }^{\circ} \mathrm{C}$ )

content, according to the following equation:

Chlorophyll $a(\mathrm{Ca})$ in $\mathrm{mg} \mathrm{g}^{-1}$ f.w. $=\left(12.7 \times \mathrm{A}^{663}-2.69 \times\right.$ $\left.\mathrm{A}^{645}\right) \times \mathrm{X} /(1000 \times \mathrm{n})$

Chlorophyll $b(\mathrm{Cb})$ in $\mathrm{mg} \mathrm{g}^{-1}$ f.w. $=\left(22.9 \times \mathrm{A}^{645}-4.68 \times\right.$

$\left.\mathrm{A}^{663}\right) \times \mathrm{X} /(1000 \times \mathrm{n})$

Total chlorophyll content $=\mathrm{Ca}+\mathrm{Cb}$,

where $\mathrm{X}$ : the final volume of dilution,

$\mathrm{n}$ : the fresh weight (f.w.) of plant tissues,

$A^{663}$ : absorbance at the wavelength of $663 \mathrm{~nm}$,

$A^{663}$ : absorbance at the wavelength of $645 \mathrm{~nm}$.

The nitrate content in the leaves was determined colorimetrically from the reduction of nitrates to nitrites through a cadmium column as described in the AOAC Official Methods of Analysis (AOAC, 1995), using a Shimadzu Spectrophotometer Model UV-1601 VIS (Shimadzu, Kyoto, Japan).

\section{Statistical analyses}

Experiments were laid out in a completely randomized design with each tank comprising one replicate $(n=3)$ for both species. Statistical analysis was performed with Statgraphics 5.1.Plus statistical package (Statistical Graphics Corporation). Data were evaluated by analysis of variance and the means of values were compared by the Least Significant Difference test $(\mathrm{LSD})(\mathrm{p}=0.05)$

\section{Results}

By increasing $\mathrm{N}$ rate from 100 to $200 \mathrm{mg} \mathrm{L}^{-1}$, the total biomass production (expressed in $g$ plant $t^{-1}$ of f.w.) and the number of leaves increased significantly for both lettuce and rocket plants (Table 2). Fresh and dry weight of the aerial part of lettuce and rocket plants increased by increasing $\mathrm{N}$ application rates from 100 to $200 \mathrm{mg} \mathrm{L}^{-1}$, resulting in higher mean fresh weight per plant by $23.5-113 \%$ and $42.7-107 \%$, in the case of lettuce and rocket respectively (Table 2 and Fig. 2). Total yield ranged from 12.0 to 41.9 and 8.0 to $30.2 \mathrm{~kg} \mathrm{~m}^{-2}$ of fresh leaves, for lettuce and rocket plants respectively. Nitrogen effect on fresh weight was more profound at 30 and 35 days after treatment initiation, for lettuce and rocket respectively, whereas after this specific stage and until harvest, significant differences in fresh weight were detected between the $\mathrm{N}$ application rates (Fig. 2). 
Table 2. Mean fresh weight $\left(\mathrm{g} \mathrm{plant}^{-1}\right)$ and number of leaves of lettuce and rocket plants in relation to nitrogen application rates for experiments 1,2 and 3 at harvest

\begin{tabular}{|c|c|c|c|c|}
\hline \multirow{3}{*}{ Nitrogen rate } & \multicolumn{2}{|c|}{ Lettuce } & \multicolumn{2}{|c|}{ Rocket } \\
\hline & $\begin{array}{c}\text { Mean fresh weight } \\
\left(\mathrm{g} \text { plant }^{-1}\right)\end{array}$ & $\begin{array}{l}\text { Number of leaves } \\
\text { plant }^{-1}\end{array}$ & $\begin{array}{l}\text { Mean fresh weight } \\
\left(\mathrm{g} \text { plant }^{-1}\right)\end{array}$ & $\begin{array}{c}\text { Number of leaves } \\
\text { plant }^{-1}\end{array}$ \\
\hline & \multicolumn{4}{|c|}{ Experiment 1} \\
\hline $100 \mathrm{mg} \mathrm{L}^{-1}$ & $299.5 \mathrm{~b}(\mathrm{~b})$ & $16.1 \mathrm{~b}(\mathrm{~b})$ & $108.9 \mathrm{c}(\mathrm{b})$ & $10.2 \mathrm{~b}(\mathrm{~b})$ \\
\hline $150 \mathrm{mg} \mathrm{L}^{-1}$ & $364.4 \mathrm{a}(\mathrm{b})$ & $17.2 \mathrm{ab}(\mathrm{b})$ & $152.0 \mathrm{~b}(\mathrm{a})$ & $10.4 \mathrm{ab}(\mathrm{b})$ \\
\hline \multirow[t]{3}{*}{$200 \mathrm{mg} \mathrm{L}^{-1}$} & $411.4 \mathrm{a}(\mathrm{b})$ & $18.9 \mathrm{a}(\mathrm{b})$ & $199.1 \mathrm{a}(\mathrm{a})$ & $11.2 \mathrm{a}(\mathrm{c})$ \\
\hline & \multicolumn{4}{|c|}{ Experiment 2} \\
\hline & \multicolumn{2}{|c|}{ Lettuce } & \multicolumn{2}{|c|}{ Rocket } \\
\hline $100 \mathrm{mg} \mathrm{L}^{-1}$ & $159.4 \mathrm{c}(\mathrm{c})$ & $16.6 \mathrm{c}(\mathrm{b})$ & $53.1 \mathrm{c}(\mathrm{c})$ & $10.9 \mathrm{c}(\mathrm{b})$ \\
\hline $150 \mathrm{mg} \mathrm{L}^{-1}$ & $236.7 \mathrm{~b}(\mathrm{c})$ & $19.1 \mathrm{~b}(\mathrm{~b})$ & $79.3 \mathrm{~b}(\mathrm{~b})$ & $12.7 \mathrm{~b}(\mathrm{~b})$ \\
\hline \multirow[t]{3}{*}{$200 \mathrm{mg} \mathrm{L}^{-1}$} & $340.0 \mathrm{a}(\mathrm{c})$ & $22.5 \mathrm{a}(\mathrm{b})$ & $110.0 \mathrm{a}(\mathrm{b})$ & $15.1 \mathrm{a}(\mathrm{b})$ \\
\hline & \multicolumn{4}{|c|}{ Experiment 3} \\
\hline & \multicolumn{2}{|c|}{ Lettuce } & \multicolumn{2}{|c|}{ Rocket } \\
\hline $100 \mathrm{mg} \mathrm{L}^{-1}$ & $451.0 \mathrm{~b}(\mathrm{a})$ & $24.0 \mathrm{~b}(\mathrm{a})$ & $141.1 \mathrm{c}(\mathrm{a})$ & $18.0 \mathrm{c}(\mathrm{a})$ \\
\hline $150 \mathrm{mg} \mathrm{L}^{-1}$ & $492.0 \mathrm{~b}(\mathrm{a})$ & $26.0 \mathrm{a}(\mathrm{a})$ & $179.1 \mathrm{~b}(\mathrm{a})$ & $23.0 \mathrm{~b}(\mathrm{a})$ \\
\hline $200 \mathrm{mg} \mathrm{L}^{-1}$ & $559.0 \mathrm{a}(\mathrm{a})$ & $27.0 \mathrm{a}(\mathrm{a})$ & $201.3 \mathrm{a}(\mathrm{a})$ & $25.0 \mathrm{a}(\mathrm{a})$ \\
\hline
\end{tabular}

${ }^{*}$ Means in the same column and the same experiment followed by different letters without parenthesis and means in the same column and the same nitrogen rate followed by different letters in parenthesis are significantly different by LSD test at $\mathrm{p}=0.05$.
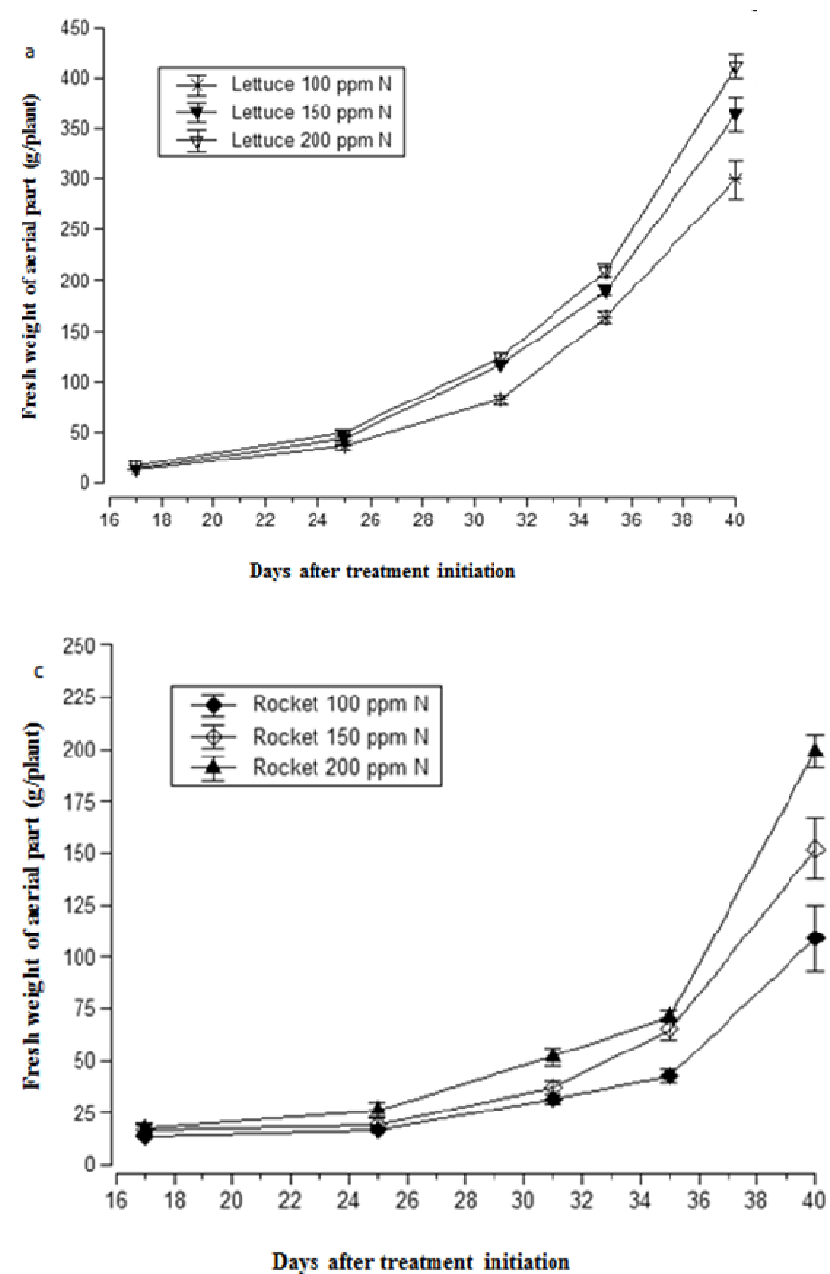
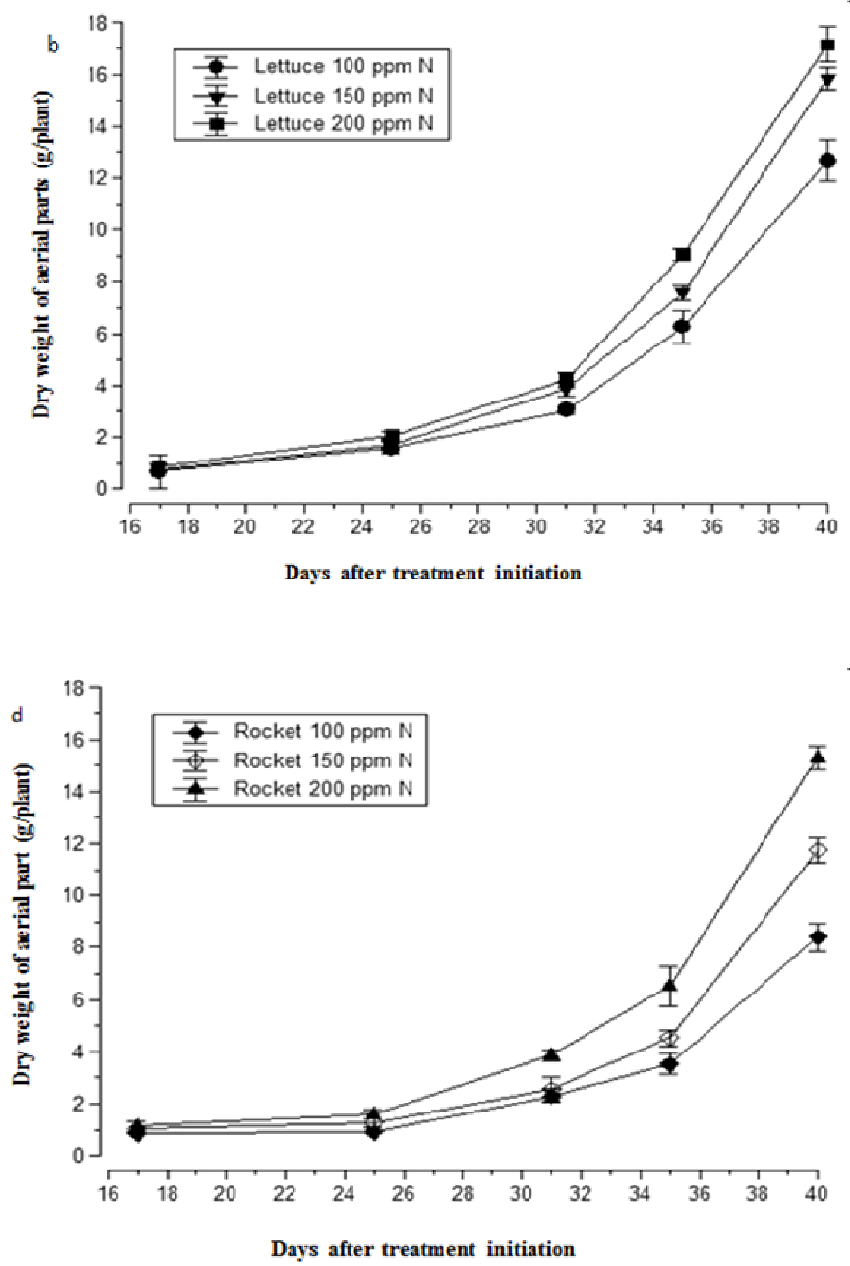

Fig. 2. The effect of nitrogen application rate on fresh and dry weight of aerial part of lettuce (a, b) and rocket (c, d) plants in relation to the number of days after treatment initiation for experiment 3

Dry matter content of lettuce leaves and roots was not affected by $\mathrm{N}$ application rates, whereas for rocket plants, increased $\mathrm{N}$ application rates resulted in higher and lower dry matter content for leaves and roots, respectively (data not shown). Significant differences were also observed for fresh weight and number of leaves of lettuce and rocket between the three experiments, with values of experiment three being significantly higher than experiment 1 and 2 . Regarding net photosynthetic and transpiration rate, both parameters increased significantly with increasing $\mathrm{N}$ application rate from 


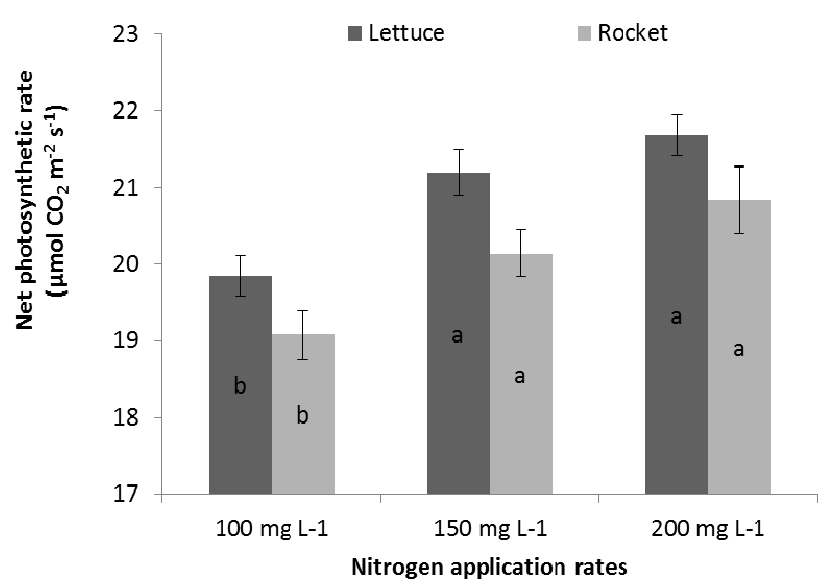

Fig. 3. Net photosynthetic rate (expressed in $\mu \mathrm{mol} \mathrm{CO} \mathrm{Cm}^{-2} \mathrm{~s}^{-1}$ ) of lettuce and rocket plants in relation to nitrogen application rate for experiment 3. Bars for each species with different letters at the same application rate are significantly different by LSD test at $\mathrm{p}=0.05$

100 to $200 \mathrm{mg} \mathrm{L}^{-1}$, especially for experiment 3 where a higher amount of degree days was observed (Figs. 3 and 4 ).

Nitrate content was significantly affected by $\mathrm{N}$ application rates, where increasing $\mathrm{N}$ content in nutrient solution from 100 to $200 \mathrm{mg} \mathrm{L}^{-1}$ resulted in a significant increase in nitrate content of leaves and roots for both lettuce and rocket plants (Table 3); however in neither case nitrate content exceeded the limit imposed by the European Commission (EC Reg. No 1258/2011) (for non-iceberg lettuce and rocket grown under glass the limit is set at 4000 and $6000 \mathrm{mg} \mathrm{kg}^{-1}$ f.w. respectively, for plants harvested between April and September), regardless of $\mathrm{N}$ application rate and growing period.

Vitamin $\mathrm{C}$ content of leaves at harvest stage was significantly affected by $\mathrm{N}$ application rates, except for lettuce in experiment 1 where no significant differences were detected;

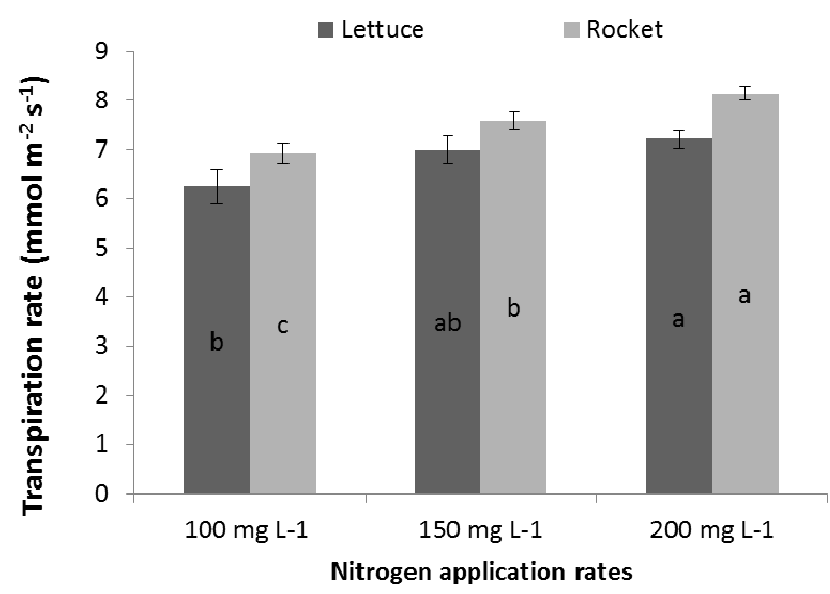

Fig. 4. Transpiration rate $\left(\mathrm{mmol} \mathrm{m}^{-2} \mathrm{~s}^{-1}\right)$ of lettuce and rocket plants in relation to nitrogen application rate for experiment 3. Bars for each species with different letters at the same application rate are significantly different by LSD test at $\mathrm{p}=0.05$

however no fixed trend of either reducing or increasing vitamin content was observed (Table 4). Mineral content of leaves and roots was affected by $\mathrm{N}$ application rates, where higher $\mathrm{N}$ rates resulted in higher content of $\mathrm{K}$ and $\mathrm{Mg}$ for both lettuce and rocket plants grown in experiment 2 (Table 5) and experiment 1 and 3 (data not shown). Mn content of lettuce and rocket leaves was also beneficially affected by increased $\mathrm{N}$ application rates in experiments 1 and 3, whereas $\mathrm{Cu}$ and $\mathrm{Zn}$ increased with increasing $\mathrm{N}$ rates only in the case of rocket leaves (data not shown).

Total chlorophyll content was either increased with increasing $\mathrm{N}$ application rate (experiments 2 and 3) or decreased (experiment 1) for both lettuce and rocket, indicating that cultivation conditions could affect both total chlorophyll content and consequently net photosynthetic rate (Table 6; Fig. 3).

Table 3. Nitrate content ( $\mathrm{mg} \mathrm{kg}^{-1}$ of f.w.) lettuce and rocket leaves and roots in relation to nitrogen application rate for experiments 1,2 and 3 at harvest

\begin{tabular}{|c|c|c|c|c|}
\hline \multirow{3}{*}{ Nitrogen rate } & \multicolumn{2}{|c|}{ Lettuce } & \multicolumn{2}{|c|}{ Rocket } \\
\hline & Leaves & Roots & Leaves & Roots \\
\hline & \multicolumn{4}{|c|}{ Experiment 1} \\
\hline $100 \mathrm{mg} \mathrm{L}^{-1}$ & $274.9 \mathrm{c}(\mathrm{b})$ & $158.2 \mathrm{c}(\mathrm{b})$ & $693.2 \mathrm{~b}(\mathrm{a})$ & $98.4 \mathrm{c}(\mathrm{b})$ \\
\hline $150 \mathrm{mg} \mathrm{L}^{-1}$ & $363.3 \mathrm{~b}(\mathrm{~b})$ & $372.5 \mathrm{~b}(\mathrm{a})$ & $763.2 \mathrm{~b}(\mathrm{a})$ & $234.2 \mathrm{~b}(\mathrm{a})$ \\
\hline \multirow[t]{2}{*}{$200 \mathrm{mg} \mathrm{L}^{-1}$} & $454.3 \mathrm{a}(\mathrm{b})$ & $442.1 \mathrm{a}(\mathrm{a})$ & $866.6 \mathrm{a}(\mathrm{a})$ & $299.6 \mathrm{a}(\mathrm{ab})$ \\
\hline & \multicolumn{4}{|c|}{ Experiment 2} \\
\hline $100 \mathrm{mg} \mathrm{L}^{-1}$ & $246.2 \mathrm{c}(\mathrm{b})$ & $196.9 \mathrm{c}(\mathrm{a})$ & $575.2 \mathrm{c}(\mathrm{b})$ & $130.5 \mathrm{c}(\mathrm{a})$ \\
\hline $150 \mathrm{mg} \mathrm{L}^{-1}$ & $395.6 \mathrm{a}(\mathrm{b})$ & $228.2 \mathrm{~b}(\mathrm{~b})$ & $721.0 \mathrm{~b}(\mathrm{~b})$ & $178.9 \mathrm{~b}(\mathrm{~b})$ \\
\hline \multirow[t]{2}{*}{$200 \mathrm{mg} \mathrm{L}^{-1}$} & $413.4 \mathrm{a}(\mathrm{c})$ & $252.6 \mathrm{a}(\mathrm{c})$ & $761.4 \mathrm{a}(\mathrm{b})$ & $274.6 \mathrm{a}(\mathrm{b})$ \\
\hline & \multicolumn{4}{|c|}{ Experiment 3} \\
\hline $100 \mathrm{mg} \mathrm{L}^{-1}$ & $315.6 \mathrm{c}(\mathrm{a})$ & $143.3 \mathrm{c}(\mathrm{b})$ & $482.8 \mathrm{c}(\mathrm{c})$ & $145.2 \mathrm{c}(\mathrm{a})$ \\
\hline $150 \mathrm{mg} \mathrm{L}^{-1}$ & $450.7 \mathrm{~b}(\mathrm{a})$ & $202.0 \mathrm{~b}(\mathrm{~b})$ & $552.0 \mathrm{~b}(\mathrm{c})$ & $264.3 \mathrm{~b}(\mathrm{a})$ \\
\hline $200 \mathrm{mg} \mathrm{L}^{-1}$ & $569.9 \mathrm{a}(\mathrm{a})$ & $301.4 \mathrm{a}(\mathrm{b})$ & $591.5 \mathrm{a}(\mathrm{c})$ & $323.0 \mathrm{a}(\mathrm{a})$ \\
\hline
\end{tabular}

${ }^{*}$ Means in the same column and the same experiment followed by different letters without parenthesis and means in the same column and the same nitrogen rate followed by different letters in parenthesis are significantly different by LSD test at $\mathrm{p}=0.05$ 
608

Table 4. Vitamin $\mathrm{C}$ content (expressed in $\mathrm{mg} \mathrm{kg}^{-1}$ f.w.) of lettuce and rocket leaves in relation to nitrogen application rates and the number of days after treatment initiation, for experiments 1,2 and 3

\begin{tabular}{|c|c|c|c|c|}
\hline \multirow{3}{*}{ Nitrogen rate } & \multicolumn{4}{|c|}{ Lettuce } \\
\hline & 18 Days & 25 Days & 31 Days & 40 Days \\
\hline & \multicolumn{4}{|c|}{ Experiment 1} \\
\hline $100 \mathrm{mg} \mathrm{L}^{-1}$ & $557 \mathrm{a}(\mathrm{c})$ & $532 \mathrm{a}(\mathrm{b})$ & $622 \mathrm{~b}(\mathrm{~b})$ & $546 \mathrm{a}(\mathrm{b})$ \\
\hline $150 \mathrm{mg} \mathrm{L}^{-1}$ & $539 \mathrm{a}(\mathrm{b})$ & $472 \mathrm{a}(\mathrm{c})$ & $721 \mathrm{a}(\mathrm{b})$ & $492 \mathrm{a}(\mathrm{c})$ \\
\hline \multirow[t]{2}{*}{$200 \mathrm{mg} \mathrm{L}^{-1}$} & $559 \mathrm{a}(\mathrm{b})$ & $456 \mathrm{a}(\mathrm{b})$ & $610 \mathrm{~b}(\mathrm{c})$ & $598 \mathrm{a}(\mathrm{b})$ \\
\hline & \multicolumn{4}{|c|}{ Experiment 2} \\
\hline $100 \mathrm{mg} \mathrm{L}^{-1}$ & $1378 \mathrm{c}(\mathrm{a})$ & $515 \mathrm{~b}(\mathrm{~b})$ & $489 c(c)$ & $470 \mathrm{~b}(\mathrm{c})$ \\
\hline $150 \mathrm{mg} \mathrm{L}^{-1}$ & $1561 \mathrm{~b}(\mathrm{a})$ & $602 \mathrm{~b}(\mathrm{~b})$ & $585 \mathrm{~b}(\mathrm{c})$ & $542 \mathrm{~b}(\mathrm{~b})$ \\
\hline \multirow[t]{2}{*}{$200 \mathrm{mg} \mathrm{L}^{-1}$} & $2165 \mathrm{a}(\mathrm{a})$ & $757 \mathrm{a}(\mathrm{a})$ & $675 \mathrm{a}(\mathrm{b})$ & $719 \mathrm{a}(\mathrm{a})$ \\
\hline & \multicolumn{4}{|c|}{ Experiment 3} \\
\hline $100 \mathrm{mg} \mathrm{L}^{-1}$ & $759 \mathrm{a}(\mathrm{b})$ & 915 a(a) & $971 \mathrm{a}(\mathrm{a})$ & 989 a(a) \\
\hline $150 \mathrm{mg} \mathrm{L}^{-1}$ & $588 \mathrm{~b}(\mathrm{~b})$ & $777 \mathrm{~b}(\mathrm{a})$ & $839 \mathrm{~b}(\mathrm{a})$ & $847 \mathrm{~b}(\mathrm{a})$ \\
\hline \multirow[t]{3}{*}{$200 \mathrm{mg} \mathrm{L}^{-1}$} & $564 \mathrm{~b}(\mathrm{~b})$ & $716 c(b)$ & $733 c(a)$ & $740 \quad c(a)$ \\
\hline & \multicolumn{4}{|c|}{ Rocket } \\
\hline & \multicolumn{4}{|c|}{ Experiment 1} \\
\hline $100 \mathrm{mg} \mathrm{L}^{-1}$ & $934 \mathrm{a}(\mathrm{c})$ & $934 \mathrm{~b}(\mathrm{c})$ & $1112 \mathrm{a}(\mathrm{b})$ & $1405 \mathrm{a}(\mathrm{a})$ \\
\hline $150 \mathrm{mg} \mathrm{L}^{-1}$ & $744 \mathrm{~b}(\mathrm{c})$ & $1098 \mathrm{a}(\mathrm{c})$ & $1105 \mathrm{a}(\mathrm{b})$ & $1224 \mathrm{c}(\mathrm{a})$ \\
\hline \multirow[t]{2}{*}{$200 \mathrm{mg} \mathrm{L}^{-1}$} & $778 \mathrm{~b}(\mathrm{c})$ & $1001 \mathrm{ab}(\mathrm{b})$ & $1073 \mathrm{a}(\mathrm{b})$ & $1307 \mathrm{~b}(\mathrm{a})$ \\
\hline & \multicolumn{4}{|c|}{ Experiment 2} \\
\hline $100 \mathrm{mg} \mathrm{L}^{-1}$ & $2011 \mathrm{a}(\mathrm{a})$ & $1070 \mathrm{~b}(\mathrm{~b})$ & $1038 \mathrm{~b}(\mathrm{c})$ & $1027 \mathrm{~b}(\mathrm{c})$ \\
\hline $150 \mathrm{mg} \mathrm{L}^{-1}$ & $2129 a(a)$ & $1247 \mathrm{a}(\mathrm{a})$ & $1096 \mathrm{~b}(\mathrm{~b})$ & $1131 \mathrm{a}(\mathrm{b})$ \\
\hline \multirow[t]{2}{*}{$200 \mathrm{mg} \mathrm{L}^{-1}$} & $2138 \mathrm{a}(\mathrm{a})$ & $1299 \mathrm{a}(\mathrm{a})$ & $1174 \mathrm{a}(\mathrm{a})$ & $1145 \mathrm{a}(\mathrm{b})$ \\
\hline & \multicolumn{4}{|c|}{ Experiment 3} \\
\hline $100 \mathrm{mg} \mathrm{L}^{-1}$ & $1176 \mathrm{a}(\mathrm{b})$ & $1206 \mathrm{a}(\mathrm{a})$ & $1219 \mathrm{a}(\mathrm{a})$ & 1238 a(b) \\
\hline $150 \mathrm{mg} \mathrm{L}^{-1}$ & $1118 \mathrm{~b}(\mathrm{~b})$ & $1134 \mathrm{~b}(\mathrm{~b})$ & $1150 \mathrm{~b}(\mathrm{a})$ & $1175 \mathrm{a}(\mathrm{b})$ \\
\hline $200 \mathrm{mg} \mathrm{L}^{-1}$ & $993 \mathrm{c}(\mathrm{b})$ & $1007 \mathrm{c}(\mathrm{b})$ & $1068 c(b)$ & $1071 \mathrm{~b}(\mathrm{c})$ \\
\hline
\end{tabular}

${ }^{*}$ Means in the same column and the same experiment for each species followed by different letters without parenthesis and means in the same column and the same nitrogen rate for each species followed by different letters in parenthesis are significantly different by LSD test at $\mathrm{p}=0.05$

\section{Discussion}

In the present study the $\mathrm{N}$ application rate affected significantly physiology, yield and quality of both lettuce and rocket plants. Nitrogen rates of 150 and $200 \mathrm{mg} \mathrm{L}^{-1}$ resulted in plants of marketable size (fully grown plants) for all the growing periods. Moreover, number of leaves showed similar trends with fresh weight of leaves which is very important, since in many markets lettuce and rocket are sold by piece (heads) and bunches of leaves respectively, and not by weight. However, considering that consumers usually prefer larger lettuce heads, the application of higher $\mathrm{N}$ rates $\left(200 \mathrm{mg} \mathrm{L}^{-1}\right)$ could increase both total yield and mean plant weight, as well as the number of leaves, rendering the use of float culture as a useful means not only for seedlings and baby vegetables production but also for fully grown plants. Furthermore, by using float culture systems farmers are enabled to adjust $\mathrm{N}$ application rate and harvesting time according to the demands of the market that the final produce is intended to, while they can also significantly increase plant density ( 75 and 150 plants $\mathrm{m}^{-2}$ for lettuce and rocket respectively) and consequently increase total yield.

Growing conditions (different temperatures between the three experiments of the present study) had also a significant effect on the number of leaves and consequently on plant fresh weight total yield, since the higher degree days of experiment three (93.3 and 27.9 for April and May, respectively) resulted in higher yield than the other two experiments (71.2 and 22 and 64.7 and 24.4, for April and May of experiment 1 and 2, respectively). Similar results have been reported by Richardson and Redgrave (1992), who suggested that not only temperature but also nitrogen fertilizer rate may affect head weight and total yield of lettuce grown in a glasshouse. The higher amount of degree days during experiment 3 may also explain the higher transpiration and net photosynthesis rate, comparing to experiments 1 and 2, since the positive correlation of temperature increase with the abovementioned physiology processes is already well confirmed in the literature (Jie and Hong, 1998). 
Table 5. Mineral content (expressed in $\mu \mathrm{mol} \mathrm{g}{ }^{-1}$ d.w.) of lettuce and rocket leaves and roots in relation to nitrogen application rates for experiment 2 at harvest

\begin{tabular}{|c|c|c|c|c|c|c|}
\hline \multirow{3}{*}{ Nitrogen rate } & \multicolumn{6}{|c|}{ Mineral content of leaves $\left(\mu \mathrm{mol} \mathrm{g}^{-1}\right)$} \\
\hline & \multicolumn{6}{|c|}{ Lettuce } \\
\hline & K & $\mathrm{Mg}$ & $\mathrm{Mn}$ & $\mathrm{Fe}$ & $\mathrm{Cu}$ & $\mathrm{Zn}$ \\
\hline $100 \mathrm{mg} \mathrm{L}^{-1}$ & $2941.2 b$ & $177.0 \mathrm{~b}$ & $1.247 \mathrm{~b}$ & $16.6 \mathrm{a}$ & $0.114 \mathrm{a}$ & $0.813 \mathrm{a}$ \\
\hline $150 \mathrm{mg} \mathrm{L}^{-1}$ & $3077.6 \mathrm{~b}$ & $209.4 \mathrm{a}$ & $1.394 \mathrm{a}$ & $15.5 b$ & $0.105 \mathrm{a}$ & $0.804 \mathrm{a}$ \\
\hline \multirow[t]{2}{*}{$200 \mathrm{mg} \mathrm{L}^{-1}$} & $3410.1 \mathrm{a}$ & $213.4 \mathrm{a}$ & $1.459 \mathrm{a}$ & $15.3 \mathrm{~b}$ & $0.990 \mathrm{a}$ & $0.814 \mathrm{a}$ \\
\hline & \multicolumn{6}{|c|}{ Rocket } \\
\hline $100 \mathrm{mg} \mathrm{L}^{-1}$ & $2156.9 c$ & $215.5 b$ & $1.065 \mathrm{~b}$ & $14.3 \mathrm{~b}$ & $0.126 \mathrm{a}$ & $0.837 \mathrm{a}$ \\
\hline $150 \mathrm{mg} \mathrm{L}^{-1}$ & $2382.8 \mathrm{~b}$ & $245.6 \mathrm{a}$ & $0.973 \mathrm{~b}$ & $15.2 \mathrm{a}$ & $0.118 \mathrm{a}$ & $0.738 \mathrm{a}$ \\
\hline \multirow[t]{3}{*}{$200 \mathrm{mg} \mathrm{L}^{-1}$} & $2698.2 \mathrm{a}$ & $256.5 \mathrm{a}$ & $1.313 \mathrm{a}$ & $14.5 b$ & $0.076 \mathrm{~b}$ & $0.820 \mathrm{a}$ \\
\hline & \multicolumn{6}{|c|}{ Mineral content of roots $\left(\mu \mathrm{mol} \mathrm{g}^{-1}\right)$} \\
\hline & \multicolumn{6}{|c|}{ Lettuce } \\
\hline $100 \mathrm{mg} \mathrm{L}^{-1}$ & $1892.6 \mathrm{~b}$ & $168.1 \mathrm{~b}$ & $5.991 \mathrm{~b}$ & $71.9 \mathrm{~b}$ & $0.024 b$ & $0.512 c$ \\
\hline $150 \mathrm{mg} \mathrm{L}^{-1}$ & $2276.2 \mathrm{a}$ & $182.5 \mathrm{a}$ & $8.601 \mathrm{a}$ & $73.2 \mathrm{~b}$ & $0.013 \mathrm{~b}$ & $1.136 \mathrm{~b}$ \\
\hline \multirow[t]{2}{*}{$200 \mathrm{mg} \mathrm{L}^{-1}$} & $2352.9 \mathrm{a}$ & $194.0 \mathrm{a}$ & $7.732 \mathrm{a}$ & $98.7 \mathrm{a}$ & $0.069 a$ & $2.154 \mathrm{a}$ \\
\hline & \multicolumn{6}{|c|}{ Rocket } \\
\hline $100 \mathrm{mg} \mathrm{L}^{-1}$ & $1713.5 \mathrm{~b}$ & $141.7 \mathrm{~b}$ & $2.087 \mathrm{~b}$ & $52.3 \mathrm{a}$ & $0.387 \mathrm{~b}$ & $2.063 \mathrm{a}$ \\
\hline $150 \mathrm{mg} \mathrm{L}^{-1}$ & $1790.3 \mathrm{a}$ & $143.3 \mathrm{ab}$ & $4.550 \mathrm{a}$ & $53.1 \mathrm{a}$ & $0.236 \mathrm{c}$ & $1.577 \mathrm{~b}$ \\
\hline $200 \mathrm{mg} \mathrm{L}^{-1}$ & $1847.8 \mathrm{a}$ & $148.4 \mathrm{a}$ & $2.129 b$ & $50.9 a$ & $0.599 a$ & $1.600 \mathrm{~b}$ \\
\hline
\end{tabular}

Fallovo et al. (2009b) have also reported a significant effect of both growing season (spring and summer) and nutrient solution composition on growth and yield of lettuce plants grown in floating raft culture; however the reported total yields and mean plant weight were lower, mainly due to higher plant density $\left(1857\right.$ plants $\left.\mathrm{m}^{-2}\right)$ and harvesting at an earlier stage (2225 days after sowing) comparing to the present study. Kotsiras et al. (2016) have reported significantly lower total yields than the present study (4.0 to $9.0 \mathrm{~kg} \mathrm{~m}^{-2}$ of fresh weight), a difference that could be attributed to the different lettuce types (Butterhead, Lollo Rosso and Batavia) and plant densities (2030 plants $\mathrm{m}^{-2}$ ), comparing to the present study.

Cultivation system affects significantly yield and earliness (date of harvest) of leafy vegetables. Nicola et al. (2005) and Fontana and Nicola (2009) compared cultivation of rocket and lettuce plants in soil and soilless media (floating systems and soil substrates) and reported higher yield and early maturity for floating system culture comparing to conventional soil culture. Higher yield in floating systems could be attributed to higher $\mathrm{N}$ content and availability in nutrient solution, which resulted in increased photosynthetic rate and consequently in increased fresh and dry weight of aerial parts of lettuce and rocket plants. Arancon et al. (2015) have also studied the effect of the growth substrate of seedling tubes in hydroponic systems and reported that transplants grown in coconut husk/sphagnum tubes had higher yield and faster growth than transplants grown in peat-based growing medium.

In the present study, total chlorophyll content in lettuce and rocket leaves was affected by $\mathrm{N}$ application rate, without however a fixed trend to be observed, while differences were also detected between the three experiments for both lettuce and rocket. According to Fallovo et al. (2009a,b), total chlorophyll content in lettuce leaves is affected mostly by growing season and nutrient solution composition; therefore, the proportion of macro-anions and macro-cations, as well as their concentration within the nutrient solution causes a quadratic instead of a linear increase in total chlorophyll content.

The higher nitrate content in lettuce and rocket leaves when $200 \mathrm{mg} \mathrm{L}^{-1}$ of $\mathrm{N}$ were applied indicates the use of nitrates as an osmoregulator factor, while carbohydrates and other photoassimilates are available for biosynthetic processes and plant growth and development. Therefore, the amount of applied $\mathrm{N}$ during cultivation should be controlled in order to avoid excessive nitrate content within plant tissues. High nitrate content in plant tissues could be attributed to high nutrient uptake from plants when grown in soilless cultures (Rouphael et al., 2004; Fallovo et al. 2009a,b; Nicola et al., 2005; Coronel et al., 2009; Fontana and Nicola, 2009; Manzocco et al., 2011), since leafy vegetables such as lettuce and rocket tend to accumulate nitrates in their leaves in order to maintain high turgor pressure. Although lettuce is considered a nitrate accumulator and one of the major sources of nitrate intake in human diet (Di Gioia et al., 2013), the highest rate of $\mathrm{N}\left(200 \mathrm{mg} \mathrm{L}^{-1}\right)$ implemented in the present study did not result in nitrate content higher than the limits allowed in E.U. This could be attributed to late harvesting ( 40 days after transplanting), since according to Yosoff et al. (2015), harvest stage can affect nitrate content in butterhead lettuce leaves, with late harvests (41 days after transplanting) significantly reducing nitrate content. Moreover, growing period has a great effect on nitrate content in lettuce leaves due to seasonal differences in solar radiation and consequently in nitrate reductase activity (Petropoulos et al., 2011). The fact 
610

Table 6. Total chlorophyll content (expressed in $\mathrm{mg} \mathrm{kg}^{-1}$ f.w.) of lettuce and rocket leaves in relation to nitrogen application rates and the number of days after treatment initiation, for experiments 1,2 and 3

\begin{tabular}{|c|c|c|c|c|}
\hline \multirow{3}{*}{ Nitrogen rate } & 11 Days & 25 Days & 31 Days & 40 Days \\
\hline & \multicolumn{4}{|c|}{ Lettuce } \\
\hline & \multicolumn{4}{|c|}{ Experiment 1} \\
\hline $100 \mathrm{mg} \mathrm{L}^{-1}$ & $8.7 \mathrm{a}(\mathrm{b})$ & $8.9 \mathrm{~b}(\mathrm{a})$ & $11.2 \mathrm{~b}(\mathrm{a})$ & $15.7 \mathrm{a}(\mathrm{a})$ \\
\hline $150 \mathrm{mg} \mathrm{L}^{-1}$ & $8.9 \mathrm{a}(\mathrm{b})$ & $8.6 \mathrm{~b}(\mathrm{c})$ & $12.2 \mathrm{a}(\mathrm{a})$ & $12.2 \mathrm{~b}(\mathrm{a})$ \\
\hline \multirow[t]{2}{*}{$200 \mathrm{mg} \mathrm{L}^{-1}$} & $9.3 \mathrm{a}(\mathrm{b})$ & $10.7 \mathrm{a}(\mathrm{b})$ & $12.9 \mathrm{a}(\mathrm{a})$ & $12.1 \mathrm{~b}(\mathrm{a})$ \\
\hline & \multicolumn{4}{|c|}{ Experiment 2} \\
\hline $100 \mathrm{mg} \mathrm{L}^{-1}$ & $10.0 \mathrm{a}(\mathrm{a})$ & $9.2 \mathrm{~b}(\mathrm{a})$ & $9.4 \mathrm{~b}(\mathrm{~b})$ & $11.5 \mathrm{a}(\mathrm{b})$ \\
\hline $150 \mathrm{mg} \mathrm{L}^{-1}$ & $10.1 \mathrm{a}(\mathrm{a})$ & $10.1 \mathrm{a}(\mathrm{b})$ & $10.1 \mathrm{a}(\mathrm{b})$ & $10.4 \mathrm{~b}(\mathrm{~b})$ \\
\hline \multirow[t]{2}{*}{$200 \mathrm{mg} \mathrm{L}^{-1}$} & $10.6 \mathrm{a}(\mathrm{a})$ & $10.3 \mathrm{a}(\mathrm{b})$ & $10.5 \mathrm{a}(\mathrm{c})$ & $11.2 \mathrm{a}(\mathrm{b})$ \\
\hline & \multicolumn{4}{|c|}{ Experiment 3} \\
\hline $100 \mathrm{mg} \mathrm{L}^{-1}$ & $8.6 \mathrm{c}(\mathrm{b})$ & $9.3 \mathrm{c}(\mathrm{a})$ & $9.2 \mathrm{c}(\mathrm{b})$ & $10.1 \mathrm{c}(\mathrm{c})$ \\
\hline $150 \mathrm{mg} \mathrm{L}^{-1}$ & $9.8 \mathrm{~b}(\mathrm{a})$ & $10.8 \mathrm{~b}(\mathrm{a})$ & $9.9 \mathrm{~b}(\mathrm{~b})$ & $10.9 b(b)$ \\
\hline \multirow[t]{3}{*}{$200 \mathrm{mg} \mathrm{L}^{-1}$} & $10.7 \mathrm{a}(\mathrm{a})$ & $11.8 \mathrm{a}(\mathrm{a})$ & $11.8 \mathrm{a}(\mathrm{b})$ & $11.6 \mathrm{a}(\mathrm{ab})$ \\
\hline & \multicolumn{4}{|c|}{ Rocket } \\
\hline & \multicolumn{4}{|c|}{ Experiment 1} \\
\hline $100 \mathrm{mg} \mathrm{L}^{-1}$ & $9.3 c(a)$ & $10.4 \mathrm{~b}(\mathrm{a})$ & $9.2 \mathrm{~b}(\mathrm{~b})$ & $13.8 \mathrm{a}(\mathrm{a})$ \\
\hline $150 \mathrm{mg} \mathrm{L}^{-1}$ & $10.2 \mathrm{~b}(\mathrm{a})$ & $13.3 \mathrm{a}(\mathrm{a})$ & $11.4 \mathrm{a}(\mathrm{b})$ & $14.3 \mathrm{a}(\mathrm{a})$ \\
\hline \multirow[t]{2}{*}{$200 \mathrm{mg} \mathrm{L}^{-1}$} & $11.0 \mathrm{a}(\mathrm{a})$ & $12.8 \mathrm{a}(\mathrm{a})$ & $11.7 \mathrm{a}(\mathrm{b})$ & $12.5 \mathrm{~b}(\mathrm{~b})$ \\
\hline & \multicolumn{4}{|c|}{ Experiment 2} \\
\hline $100 \mathrm{mg} \mathrm{L}^{-1}$ & $9.6 c(a)$ & $10.8 \mathrm{~b}(\mathrm{a})$ & $12.8 \mathrm{~b}(\mathrm{a})$ & $13.6 \mathrm{~b}(\mathrm{a})$ \\
\hline $150 \mathrm{mg} \mathrm{L}^{-1}$ & $10.5 \mathrm{~b}(\mathrm{a})$ & $12.3 \mathrm{a}(\mathrm{b})$ & $13.1 \mathrm{~b}(\mathrm{a})$ & $14.3 \mathrm{a}(\mathrm{a})$ \\
\hline \multirow[t]{2}{*}{$200 \mathrm{mg} \mathrm{L}^{-1}$} & $11.3 \mathrm{a}(\mathrm{a})$ & $13.5 \mathrm{a}(\mathrm{a})$ & $14.4 \mathrm{a}(\mathrm{a})$ & $14.6 \mathrm{a}(\mathrm{a})$ \\
\hline & \multicolumn{4}{|c|}{ Experiment 3} \\
\hline $100 \mathrm{mg} \mathrm{L}^{-1}$ & $6.7 c(b)$ & $7.7 \mathrm{c}(\mathrm{b})$ & $7.9 \mathrm{c}(\mathrm{c})$ & $8.4 \mathrm{~b}(\mathrm{~b})$ \\
\hline $150 \mathrm{mg} \mathrm{L}^{-1}$ & $8.5 \mathrm{~b}(\mathrm{~b})$ & $9.2 \mathrm{~b}(\mathrm{c})$ & $8.8 \mathrm{~b}(\mathrm{c})$ & $9.9 \mathrm{a}(\mathrm{b})$ \\
\hline $200 \mathrm{mg} \mathrm{L}^{-1}$ & $10.2 \mathrm{a}(\mathrm{b})$ & $10.8 \mathrm{a}(\mathrm{c})$ & $10.1 \mathrm{a}(\mathrm{c})$ & $11.0 \mathrm{a}(\mathrm{c})$ \\
\hline
\end{tabular}

${ }^{*}$ Means in the same column and the same experiment for each species followed by different letters without parenthesis and means in the same column and the same nitrogen rate for each species followed by different letters in parenthesis are significantly different by LSD test at $\mathrm{p}=0.05$

that all the experiments in the present study were conducted during spring where light intensity in Southern Europe is relatively high and enhances nitrate reductase activity, could be the main reason why the measured nitrate content was relatively low and below the limits set by the E.U. Moreover, the differences between the three experiments where nitrate content in leaves at the highest $\mathrm{N}$ application rate was higher in experiment 3 for lettuce and experiment 1 for rocket, could be attributed to differences in solar radiation and temperature and solar radiation requirements for nitrate reductase activity of each species, despite the fact that all the experiments were carried out in the same season.

Vitamin C and chlorophyll contents in leaves of lettuce and rocket were affected by $\mathrm{N}$ application rates without however a fixed trend to be observed. Luna et al. (2013) reported that vitamin $C$ content of lettuce leaves was higher when 10.05 mmol L-1 of $\mathrm{N}$ were applied, whereas no such effect was observed in the present study. This difference could be attributed to the fact that they studied different genotypes of lettuce (loose-leaf and butterhead types) comparing to this study (romaine-type). Moreover, high levels of $\mathrm{N}$ application rates are usually associated with decreased vitamin $\mathrm{C}$ content in various vegetables, such as potato, and cauliflower (Lee and Kader, 2000).

Significant differences in vitamin C and chlorophyll contents were observed between the three experiments, which suggests that growing conditions may also have an effect on vitamin $\mathrm{C}$ and chlorophyll content and consequently on the quality and visual appearance of leafy vegetables, such as lettuce and rocket. According to Haldimann (1999), chlorophyll content in leaves can be affected by both temperature and solar radiation where under conditions of low temperatures and high irradiance may induce photo-oxidization of chlorophyll, before it is bound on pigment-protein complexes in thylakoid membranes. Moreover, temperature and total available heat, as well as the amount of light and light intensity have also a significant effect on vitamin $\mathrm{C}$ content in many vegetables, with high temperatures and low amounts of light resulting in low vitamin C content (Lee and Kader, 2000).

Mineral content of leaves and roots and especially $\mathrm{K}$ and 
$\mathrm{Mg}$ content was beneficially affected by $\mathrm{N}$ application rates. This increase in $\mathrm{K}$ and $\mathrm{Mg}$ content of leafy vegetables is essential for increasing product quality, since vegetables are an important source for macro and micro-elements in human nutrition. Similarly, Fallovo et al. (2009b) have reported that K and $\mathrm{Mg}$ contents in lettuce leaves were significantly affected by nutrient solution composition, especially by macro-anion and macro-cation proportions. Enhanced photosynthetic rate is also related with increased transpiration rate and mineral uptake of plants, especially for $\mathrm{K}$ and $\mathrm{Mg}$, which was the case in the present study where transpiration and net photosynthetic

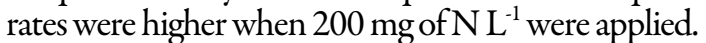

\section{Conclusions}

Plant growth and yield of lettuce and rocket grown in float culture systems is highly affected by $\mathrm{N}$ application rate, where the application of $200 \mathrm{mg} \mathrm{L}^{-1}$ of $\mathrm{N}$ resulted in significantly higher yields in terms of fresh weight and number of leaves. The application of the abovementioned rate did not cause adverse effects on the quality of the final product, especially regarding the nitrate content of leaves. Since optimum plant nutrition is essential for leafy vegetables, float culture could increase the overall product quality and added value of the final product without compromising total yield. Additionally, float culture could be used not only for seedling and baby products production, but also as an alternative cultivation system for vegetable production of fully grown plants with significantly high yields and high quality.

\section{References}

AOAC (1995). Nitrogen (nitrate and nitrite) in animal feed. Official Methods of Analysis 4:1415.

Arancon NQ, SchafferN, ConverseCE (2015).Effects of coconut husk and sphagnum moss-based media on growth and yield of romaine and buttercrunch lettuce (Lactuca sativa) in a non-circulating hydroponics system.Journal of Plant Nutrition 38:1218-1230.

Bajaj LK, Kaur G (1981). Spectrophotometric determination of L-ascorbic acid in vegetables and fruits. Analyst 106:117-120.

Campbell CR, Plank CO (1998). Preparation of plant tissue for laboratory analysis. In: Kalra YP (Ed). Handbook of Reference Method for Plant Analysis. CRC Press, Boca Raton, Floridapp 37-49.

Colla G, Rouphael Y, Cardarelli M, Svecova E, Rea E, Lucini L (2012). Effects of saline stress on mineral composition, phenolic acids and flavonoids in leaves of artichoke and cardoon genotypes grown in floating system. Journal of the Science of Food and Agriculture 93:11191127.

ConesaE, Ninirola D, Vicente MJ, OchoaJ, Banon S, FernandezJA (2009). The influence of nitrate/ammonium ratio on yield quality and nitrate, oxalate and vitamin C content of babyleaf spinach and bladder campion plants grown in a floating system. Acta Horticulturae 843:137-144.

Coronel G, Chang M, Rodriguez-Delfin A (2009). Nitrate reductase activity and chlorophyll content in lettuce plants grown hydroponically and organically. Acta Horticulturae 843:137-144.

Default RJ, Ward B, Hassell RL (2006). Planting date and romaine lettuce cultivar affect quality and productivity. HortScience 41:640-645.
Di Gioia F, Gonnella M, Santamaria P (2013). Contribution of leafy vegetables to dietary nitrate intake and regulations. In: Umar S, Anjum NA, Khan NA (Eds). Nitrate in leafy vegetables: Toxicity and safety measures. I.K. International Publishing 331 House Pvt Ltd, New Delhi, Bangalore pp 2-16.

EU Commision (2011). Commission Regulation (EC) No. 1258/2011 of 2 December 2011 amending Regulation (EC) No 1881/2006 as regards maximum levels for nitrates in foodstuffs. Official Journal of European Union L320:15-17.

Fallovo C, Rouphael Y, Cardarelli M, Rea E, Battistelli A, Colla G (2009b). Yield and quality of leafy lettuce in response to nutrient solution composition and growing season. Journal of Food, Agriculture and Environment 7(2):456-462.

Fallovo C, Rouphael Y, Rea E, Battistelli A, Colla G (2009a). Nutrient solution concentration and growing season affect yield and quality of Lactuca sativa L. var. acephala in floating raft culture. Journal of the Science of Food and Agriculture 89(10):1682-1689.

Fontana E, Nicola S (2009). Tratidional and soilless culture systems to produce corn salad (Valerianella olitoria L.) and rocket (Eruca sativa Mill.) with low nitrate content. Journal of Food, Agriculture and Environment 7(2):405-410.

Fritschi FB, Ray JD (2007). Soybean leaf nitrogen, chlorophyll content, and chlorophylla/bratio. Photosynthetica 45(1):92-98.

Galbiatti JA, Cavalcante ÍHL, Ribeiro AG, Pissarra TCT (2007). Nitrate and sodium contents on lettuce and drained water as function of fertilizing and irrigation water quality in Brazil. International Journal of Plant Production 2:205-214.

Gonnella M, Serio F, Conversa G, Santamaria P (2001). Yield and quality of lettuce grown in floating system using different sowing density and plant spatial arrangements. Acta Horticulturae 614:687-692.

Haldimann $\mathrm{P}(1999)$ ). How do changes in temperature during growth affect leaf pigment composition and photosynthesis in Zea mays genotypes differing in sensitivity to low temperature? Journal of Experimental Botany 50(333):543-550.

Henriques F, Park R (1976). Development of the photosynthetic unit in lettuce. Cell Biology 73:4560-4564.

Jie H, Kong LS (1998). Growth and photosynthetic characteristics of lettuce (Lactuca sativa L.) under fluctuating hot ambient temperatures with the manipulation of cool root-zone temperature. Scientia Horticulturae 152(45):387-391.

Klados E, Tzortzakis N (2014). Effects of substrate and salinity in hydroponically grown Cichorium spinosum. Journal of Soil Science and PlantNutrition 14(1):211-222.

Kotsiras A, Vlachodimitropoulou A, Gerakaris A, Bakas N, Darras AI (2016). Innovative harvest practices of Butterhead, Lollo rosso and Batavia green lettuce (Lactuca sativa L.) types grown in floating hydroponic system to maintain the quality and improve storability. Scientia Horticulturae 210:1-9.

Larsson UK, Anderson JM, Andersson B (1987). Variation in the relative content of the peripheral and inner light-harversting chlorophyll $\mathrm{a} / \mathrm{b}$ protein complex (LHCII) subpopulations during thylakoid light adaptation and development. Biochimicaet Biophysica Acta 894:69-75.

Lee S.K, Kader, AA (2000). Preharvest and postharvest factors influencing 
612

vitamin C content of horticultural crops. Postharvest Biology and Technology 20(3): 207-220.

Luna MC, Martinez-Sanchez A, Selma VM, Tudela AJ, Baixauli C, Gil IM (2013). Influence of nutrient solutions in an open-field soilless system on the quality characteristics and shelf life of fresh-cut red and green lettuces (Lactuca sativa L.) in different seasons. Journal of the Science of Food and Agriculture 93:415-421.

Manzocco L, Foschia M, Tomasi N, Maifreni M, Dalla Costa L, Marino M, Cortella G, Cesco S (2011). Influence of hydroponic and soil cultivation on quality and shelflife of ready-to eat lamb's lettuce (Valerianella locusta L. Laterr). Journal of the Science of Food and Agriculture 91:13731380.

Nicola S, Hoeberechts J, Fontana E (2005). Comparison between traditional and soilless culture systems to produce rocket (Eruca sativa) with low nitrate content. Acta Horticulturae 697:549-555.

Petropoulos SA, Constantopoulou E, Karapanos I, Akoumianakis CA, Passam HC (2011). Diurnal variation in the nitrate content of parsley foliage. International Journal of Plant Production 5(4):431-438.

Richardson SJ, Hardgrave M (1992). Effect of temperature, carbon dioxide enrichment, nitrogen form and rate of nitrogen fertiliser on the yield and nitrate content of two varieties of glasshouse lettuce. Journal of the Science of Food and Agriculture 59(3):345-349.

Rouphael Y, Colla G, Battistelli A, Moscatello S, Proietti S, Rea E (2004). Yield, water requirement, nutrient uptake and fruit quality of zucchini squash grown in soil and closed soilless culture. Journal of Horticultural Science and Biotechnology 79:423-430.

Salerno A, Pierandrei F, Rea E, Colla G, Rouphael Y, Saccardo F (2005). Floating system cultivation of radish (Raphanus sativus $\mathrm{L}$.): production and quality. Acta Horticulturae 697:87-92.

Schoefs B, Bertrand M, Lemoine Y (1998). Changes in the photosynthetic pigments in bean leaves during the first photoperiod of greening and the subsequent dark-phase. Comparison between old (10-d-old) leaves and young(2-d-old) leaves. Photosynthesis Research 57(2):203-213.
Scuderi D, Giuffrida F, Noto G (2009). Effects of salinity and plant density on quality of lettuce grown in floating system for fresh-cut. Acta Horticulturae 843:219-226.

Soundy P, Cantliffe DJ (2001). Improving lettuce transplant quality in response to nitrogen nutrition in a floating production system. Proceedings of Florida State Horticultural Society 114:294-303.

Soundy P, Cantliffe DJ, Hochmuth GJ, Strofella PJ (2001). Nutrient requirements for lettuce transplants using a floatation irrigation system. I. Phosphorus. HortScience 36(6):1066-1070.

Thebud R, Santarius AK (1982). Effects of high- temperature stress on various biomembranes of leaf cells in situ and in vitro. Plant Physiology 70:200-205.

Tomasi N, Pinton R, Costa LD, Cortella G, Terzano R, Mimmo T, Scampicchio M, CescoS (2015). New 'solutions' for floating cultivation system of ready-to-eat salad: A review. Trends in Food Science and Technology 46(2):267-276.

Torres AN, Campostrini E, Goncalves de Oliveira J, Bressan-Smith RE (2005). Photosynthetic pigments, nitrogen, chlorophyll a fluorescence and SPAD-502 readings in coffee leaves. Scientia Horticulturae 104:199-209.

Wellburn AR (1994). The spectral determination of chlorophylls a and b, as well as total carotenoids, using various solvents with spectrophotometers of different resolution. Journal of Plant Physiology 144(3):307-313.

Yosoff SF, Mohamed MTM, Parvez A, Ahmad SH, Ghazali FM, Hassan $\mathrm{H}$ (2015). Production system and harvesting stage influence on nitrate content and quality of butterheadlettuce. Bragantia 74(3):322-330.

Zanin G, Ponchia G, Sambo P (2011). Yield and quality of vegetables grown in a floating system for ready-to-eat produce. Acta Horticulturae $807: 433-438$. 